New Zealand Journal of Industrial Relations, 20(3): 313-322

\title{
The Job of the Full-Time Trade Union Official
}

\author{
Grant Michelson*
}

This paper examines the work activities and work patterns of 91 New Zealand full-time union officials located at different levels in the paid trade union structure. While officials with managerial responsibilities in their unions allocated their work-time to various tasks differently compared to those in non-managerial positions, broad similarities existed in terms of how and when managerial and non-managerial union officials worked. The findings are discussed in terms of the current legislative climate in New Zealand.

\section{Introduction}

Although the existence of different levels and functions in the paid union personnel structure has long been recognised (e.g. Cupper, 1983), relatively few studies on union officials have systematically examined work differences amongst those in different organisational positions. Much of the research literature has tended to report data on the work of paid officials located at similar levels within their respective unions' structures (e.g. Adams, 1977; Brown and Lawson, 1973; Robertson and Sams, 1978). It has since been argued that the representation of the dynamics and complexities of the full-time official labour market is often under-estimated by studies such as these (Callus, 1986). The present study attempts to address this criticism by comparing the work activities and patterns of full-time trade union officials at different positions in the union structure. It therefore provides data in an area where there is presently little available. Specifically, what duties or tasks are involved in union work and how do officials allocate their time among the various activities? How many hours do union officials work? When do they work? How often does the job take them away from home? These questions are explored by reporting the results from a recent interview survey of 91 union officials in the South Island of New Zealand.

Before presenting the findings of the study, brief mention of the research context and research method are made.

The data on which this paper is based was collected nine to twelve months following a significant legislative departure from previous industrial relations policies. The Employment Contracts Act, enacted in May 1991, ushered in a completely new operating environment for unions. This environment included changes which not only substantially 


\section{Grant Michelson}

undermine the collective bargaining system but also alters union rights (Harbridge, 1993). While employers are obliged to recognise their employees' chosen "bargaining agent", there is no legal requirement to negotiate a collective employment contract. Further, the Act removes exclusive jurisdiction rights traditionally held by unions, blanket coverage, and de facto compulsory union membership. Any trade union efforts to consolidate multi-employer negotiations are obstructed by the unlawfulness of strike action over the issue of whether a collective employment contract will bind two or more employers. Among others, this feature indicates the decentralist emphasis of the Act. In an industrial climate where unionism and bargaining are entirely voluntary and employee representation is a contestable process, an investigation of the work and work patterns of full-time union officials is particularly timely.

\section{Method}

Tape-recorded interviews were conducted with 91 full-time union officials between February and May 1992. The research sample was drawn from twenty-seven different unions ranging in size from 1,100 to 60,500 members and representing a wide range of industries and occupations. The 91 officials surveyed represented a response rate of 73 percent of those from traditional unions who worked in the South Island. Specialist portfolios such as education, research, and legal officers were excluded from the population as were "non-union bargaining agents".

Because job titles can sometimes be an ambiguous indicator of position in the hierarchy, it was felt that a more appropriate method of stratifying the sample was to consider each official's relative location within their union's structure. Two groups - labelled simply as "low" and "high" - were subsequently established. Placement in the "high" organisational category was determined by the existence of formal supervisory responsibilities and/or whether an official held a position above the first tier or entry-level of the union's paid structure. Common job titles for those in the "high" category included: assistant secretary, branch secretary, branch executive officer, secretary-treasurer, and general secretary. For all intents and purposes these positions typically represent most unions' day-to-day management group. Officials who did not supervise others and who were in entry-level positions in their union's paid hierarchy, were placed in the "low" organisational category. Job titles for those in this group included: organiser, field officer, industrial officer, industrial agent, and bargaining agent.

The classification scheme resulted in 31 of the sample $(34.1 \%)$ holding "high" level or managerial union positions, with 60 officials $(65.9 \%)$ holding "low" level or non-managerial union positions. In terms of certain demographic characteristics, the average age of officials in both groups was similar. With respect to gender, while the evidence in the present study did suggest a pattern of female under-representation in "high" level union positions, this was inconclusive at conventional statistical levels (chi-square $=3.57$, df $=1, p<.06$ ). Thus, gender was ruled out as a significant discriminating variable in the study. 


\section{Union work activities}

The sample were requested to rank, in terms of the time they occupied, their four principal work activities. The results demonstrated that full-time officials perform a range of different tasks. These included: reading and writing reports, dealing with correspondence, preparing wage arrears claims, compiling and editing the union newsletter or magazine, dealing with financial matters such as budgeting, telephoning both members and employers, visiting workplaces, attending branch meetings, attending meetings with employers or with other union officials, preparing for and conducting personal grievance cases, and negotiating employment contracts. Workplace visits, administrative responsibilities, and membership advice (for example, by telephone) were the primary work activities of the sample as a whole. The nature of these three principal activities indicates that union work involves periods which are spent both in and away from the office. In general, personal grievance work, internal union meetings, other meetings, and travel were more secondary in terms of the time officials accorded to them.

The relative importance of work tasks in terms of the time they occupied, is presented separately for "low" level and "high" level union officials in Table 1. As a note of explanation the total in the first column for activities ranked first or second most time consuming adds to 120 . This was due to the 60 officials who held "low" level union positions being counted for their most time consuming activity and again for their second most time consuming activity. The same logic operates for the 31 respondents holding "higher" office in their unions where the column total equals twice the number of respondents in that category.

As might be expected and as the table illustrates, position within the union significantly affected what officials did in their jobs. Workplace visits, membership advice, and administration were the three major activities for "low" level union officials. "High" level respondents were also heavily involved in these same activities but their relative importance differed. Administration was considered the most time consuming activity, followed by workplace visits and membership advice. Even among the tasks that consumed less time (3rd or 4th ranked items), there was a different emphasis of activities among "low" and "high" level officials. Internal union meetings were more important for those in positions of responsibility $(16.1 \%)$, while "low" level respondents were more active in "other" meetings $(13.3 \%)$.

It might also be inferred from Table 1 that the importance of the bargaining function required more senior or experienced officials to negotiate employment contracts in some unions. A greater proportion of "high" level officials included negotiation work among their four principal activities. However, there were indications from the interview data that this pattern may be changing to some extent. Many "lower" level respondents expected to become more active in the near future as existing bargaining arrangements negotiated prior to the Employment Contracts Act expired. 
Table 1: Work tasks by organisational level: ranked by time

\begin{tabular}{|c|c|c|c|c|}
\hline \multirow{2}{*}{ Activity } & \multicolumn{2}{|c|}{ Low $(n=60)$} & \multicolumn{2}{|c|}{ High $(n=31)$} \\
\hline & $\begin{array}{c}\text { 1st or } \\
\mathrm{N}\end{array}$ & $\begin{array}{r}\text { ranked } \\
(\%)\end{array}$ & $\begin{array}{c}\text { 1st o } \\
\mathrm{N}\end{array}$ & $\begin{array}{r}\text { ranked } \\
(\%)\end{array}$ \\
\hline Travel & 4 & $(3.3)$ & 2 & $(3.2)$ \\
\hline Administration & 17 & $(14.2)$ & 23 & $(37.1)$ \\
\hline Workplace Visits & 47 & $(39.2)$ & 18 & $(29.0)$ \\
\hline Internal Union Meetings & 5 & $(4.2)$ & 1 & (1.6) \\
\hline Other Meetings & 1 & $(0.8)$ & 2 & $(3.2)$ \\
\hline Grievance Work & 7 & $(5.8)$ & 1 & (1.6) \\
\hline Membership Advice & 25 & $(20.8)$ & 10 & $(16.1)$ \\
\hline \multirow[t]{2}{*}{ Negotiations } & 14 & $(11.7)$ & 5 & $(8.1)$ \\
\hline & \multicolumn{2}{|c|}{ 3rd or 4th ranked } & \multicolumn{2}{|c|}{3 rd or 4 th ranked } \\
\hline Travel & 14 & $(11.7)$ & 7 & (11.3) \\
\hline Administration & 16 & $(13.3)$ & 7 & (11.3) \\
\hline Workplace Visits & 13 & $(10.8)$ & 4 & $(6.5)$ \\
\hline Internal Union Meetings & 8 & $(6.7)$ & 10 & $(16.1)$ \\
\hline Other Meetings & 16 & (13.3) & 3 & $(4.8)$ \\
\hline Grievance Work & 18 & $(15.0)$ & 7 & (11.3) \\
\hline Membership Advice & 22 & (18.3) & 10 & $(16.1)$ \\
\hline Negotiations & 13 & $(10.8)$ & 14 & $(22.6)$ \\
\hline
\end{tabular}

\section{"Outside" work commitments}

In addition to normal union-related functions, previous research suggests that union officials tend to be significantly involved in various community, industry, and government bodies or organisations linked to and/or flowing from their union positions (Robertson and Sams, 1976). Of the 91 officials surveyed for the present study, $37(40.7 \%)$ reported holding commitments relevant to but "outside" the scope of their typical day-to-day union business. These officials held anywhere from one to six "outside" commitments with two being about average. More often than not, officials who chose to involve themselves in these extra activities held "high" level or managerial positions in their unions.

The main type of responsibilities that officials were involved in included: sitting on the district executive of the New Zealand Council of Trade Unions (NZCTU), memberships of various apprenticeship committees at the relevant educational institution in the area, and participation in Labour Party Electorate Committees. Many regarded their involvement with the NZCTU as fundamental in keeping abreast of information which might affect them in 
their jobs. Membership of polytechnic committees was primarily valued by respondents for the opportunity it offered to initiate change. These types of activities also provided union officials with a different context than that typically experienced when meeting with employer representatives. Some officials believed that conditions for dealing with workplace problems were more favourable in an apprenticeship committee situation, for example, than under conventional bargaining arrangements where a more adversarial approach was usually adopted.

\section{The pattern of union work}

\section{The hours worked}

A typical first response to the question seeking information about how many hours officials worked was that "it depends", or that "it varies according to what is happening at the time". These comments suggest that the intensity of union work is subject to considerable fluctuation. There may be times of high activity but yet there may also be periods when the work pace is calmer. The amount of time that officials estimated they spent working made allowance for these fluctuations. The average number of hours reportedly worked per week by the sample was 47.1. The number of hours worked by the 60 "low" level and 31 "high" level respondents is presented separately in Table 2. Overall, officials who held "low" level union positions worked three hours less per week on average (46.1 hours) than did their colleagues in "higher" union office (49.2 hours). Statistically, the difference was more suggestive than conclusive $(\mathrm{p}<.06)$.

\section{Table 2: Hours worked by organisational level (per week)}

\begin{tabular}{lrrrrr}
\hline No. of Hours & Total & Low & $(\%)$ & High & (\%) \\
\hline$\leq 40$ hours & 23 & 18 & $(30.0)$ & 5 & $(16.1)$ \\
$41-50$ hours & 50 & 33 & $(55.0)$ & 17 & $(54.9)$ \\
$51-60$ hours & 16 & 8 & $(13.3)$ & 8 & $(25.8)$ \\
$61-70$ hours & 2 & 1 & $(1.7)$ & 1 & $(3.2)$ \\
\hline
\end{tabular}

\section{Control over hours}

Some writers have argued that the reason why officials work long hours is because they choose to do so (Clegg et al., 1961). The research sample held mixed opinions about whether or not the number of hours they worked was controllable. Some officials felt that their pattern of work was determined entirely by circumstances beyond their control, whereas at the other end of the continuum a few believed that the decision concerning how many hours they worked was theirs completely. The majority of respondents, however, fell 


\section{Grant Michelson}

somewhere between these two end points. That is, there was usually a core number of "office" hours expected from them and once this obligation was met, then variations could occur over the number of "extra" hours worked. A number of respondents held the view that full-time union work was an occupation such that there was always something to do if they were willing to do additional work; for this reason some had made the decision not to work any "extra" hours.

Closely related to the degree of control over the number of hours that were worked was the amount of control an official could exercise over when they worked. Nine officials thought they had "no control", 57 felt they had "some control", while 25 respondents believed that "most of the time" they could choose when they performed their jobs. To help protect officials from working excessively long hours some unions provided their industrial staff with time-in-lieu, compensatory leave, or glide time arrangements. Even where glide time or time-in-lieu was not a formalised union practice many still indicated they had some flexibility to "take an hour off here and there to get a haircut". In other words, an element of job control could still be exercised. The availability of glide time and time-in-lieu for any "extra" hours worked was closely related with the amount of control officials believed they had.

There was no evidence that officials in "high" level positions had more control over when they did their work than "lower" level officials. In fact, while many in union management had access to time-in-lieu arrangements, there was a reported tendency not to make use of this provision. They regarded taking time off as setting a bad example for their subordinates. This may account for the subtle pressures felt by at least one "low" level respondent not to take the time he was owed: "(The union) don't mind you working the long hours, but by the same token (people) look at you all suspiciously if you're not in your office before eight-thirty".

\section{Evening work}

Union activity is not restricted to "orthodox" working times. The liberalisation of shop trading hours and the continuous nature of many production processes has, among other factors, meant that evening and weekend work was not extraordinary for the union official occupation. Evening work featured regularly in the work pattern of most of those in the present survey, with 67 respondents $(83.5 \%)$ reportedly working one or more evenings per week (the sample averaged 1.7 evenings per week). The pattern of evening work among "low" level and "high" level officials was almost identical with an average 1.7 and 1.8 evenings worked per week, respectively. Not surprisingly, the requirement for officials to work evenings and weekends (see below) was heavily influenced by the nature of the union's membership. Where members predominantly worked day shift hours officials indicated a lower propensity to work evenings and weekends. 


\section{Weekend work}

In the case of weekend work, officials were asked whether they spent at least some of their time on weekends doing union business. Table 3 shows that most officials worked one or less weekend per month on average and that only a small proportion regularly worked on union business at some stage over the course of every weekend. The average number of weekends worked by the sample overall was 1.1 per month. The group of "low" level officials in the present study worked slightly less than one weekend per month on average $(0.9)$, with "high" level respondents tending to work more weekends (1.4) on average. However, this difference was only suggestive $(p<.10)$.

Table 3: Weekends worked by organisational level (per month)

No. of Weekends Total Low $\quad(\%) \quad$ High

\section{(\%)}

\begin{tabular}{lrrrrr} 
None ${ }^{\mathrm{a}}$ & 35 & 28 & $(46.7)$ & 7 & $(22.6)$ \\
One & 28 & 15 & $(25.0)$ & 13 & $(41.9)$ \\
Two & 19 & 14 & $(23.3)$ & 5 & $(16.1)$ \\
Three & 4 & 1 & $(1.7)$ & 3 & $(9.7)$ \\
Four & 5 & 2 & $(3.3)$ & 3 & $(9.7)$ \\
\hline
\end{tabular}

a Included respondents for whom weekend work was very irregular.

The data disclosed that having "outside" work commitments was positively related to the frequency of weekend work. As these activities generally consumed time through the Monday to Friday week, it seemed that weekend work reflected, at least in part, a "catchup" of work that was missed while officials were engaged in these extra activities. For officials who mentioned that weekend work was a regular part of their job pattern, administrative-related duties (for example, reading and writing reports, processing contracts or grievances) and meetings with the membership were by far the most common activities. Officials explained that one main reason for doing paperwork at the weekend was that the number of telephone calls received through the week often prevented them from enjoying uninterrupted time in the preparation of grievance cases, wage arrears claims, and the like. Many indicated that by going to the office at the weekend they were able to concentrate on these tasks, free from the distraction of their telephones. 


\section{Extent of jurisdiction and travel time to reach members}

A significant majority of respondents had membership servicing responsibilities which covered large geographic areas of the South Island. Sixty-seven officials $(73.6 \%)$ had a one-way travel time of one or more hours from their union offices to service their particular members. Sixteen officials were responsible for groups of members located wholly or principally within a major urban centre and surrounding areas only, while only eight respondents were not personally responsible for servicing a specific "patch" or territory. Driving time for those sampled ranged from zero to eight hours and when the few officials who did not have servicing responsibilities were excluded, the average one-way travelling time was quite high - about three and one-half hours to reach the most distant group of members. There were no significant differences in the average travel time for "low" level and "high" level union officials.

\section{Nights spent away from home}

For $70(76.9 \%)$ of the 91 officials sampled, regular overnight stays in other centres were part of the work routine. Predictably, the number of nights spent out of town was a function of the geographic area that an official was responsible for with a significant relation between the time it took officials to drive to their memberships, and the average number of nights away. For those who spent periods away from home on union business the usual number of nights per month extended up to twelve, but this figure was rare - one to five nights being more typical. That is, the distribution of officials who reported being away one to five nights per month was similar. There were no significant differences in the number of nights that "low" level and "high" level union officials regularly spent away from home.

Absences from home had some impact on other areas of union officials work patterns. The more often they were away, the more hours and evenings that individuals tended to work. Some remarked that they worked longer hours when visiting other centres either because there was nothing else for them to do or, related to this, because they did not have their normal family responsibilities to attend to. One respondent commented: "I don't mind putting in the extra hours because you're staying in a motel, so if you get back too early (to the motel after a day's work) it's boring".

\section{Conclusions}

This article has examined the work activities and work patterns of full-time trade union officials who held different relative positions within their unions' structures. Workplace visits, administration, and membership advice were identified as primary work activities for all officials, with the importance of each varying by location in the union hierarchy. Administrative-related duties were more likely to consume more work time for "high" level officials, while workplace visits were more time consuming for those holding lower level positions in their unions. "Low" level officials worked an average of about 46 hours per 
week, three hours less than those higher up in their unions. This difference could probably be explained almost entirely by the more active involvement of the managerial respondents in "outside" work commitments. While patterns between the two groups of officials were similar with respect to the extent of felt work control, evening work, travelling time, and nights spent away from home, there were some indications that those in higher level union office were more often involved in weekend work. In part, this too appeared to be a corollary of their "outside" work responsibilities. This study has demonstrated, therefore, the need to treat full-time union officials as a heterogeneous rather than homogeneous group when analysing their work activities and patterns.

The results were found notwithstanding the changed industrial environment introduced by the Employment Contracts Act and, related to this, in a context characterised by declining trade union density (Harbridge and Hince, 1993). However, as no pre-Act data was available, this paper is unable to report the extent to which officials' work patterns have been affected by the new Act. Having said this, union officials are undoubtedly required to work more hours in an operating environment which has completely abandoned all traditional legislated union supports than one in which such supports exist. Whether or not this has occurred among the present sample is uncertain. Perhaps there will be both those who find the results of this survey somewhat pessimistic (e.g. the data does not necessarily suggest a pattern of excessive work effort) as well as encouraging (e.g. many officials are actively visiting and most likely shoring up their memberships). Future research which tests the influence (if any) of changes in the Act on the work of union officials would therefore be of value and interest here. As this study was concerned with painting a broad picture of the work activities and patterns of union officials across a number of unions of varying size, other discriminating variables besides organisational level might reveal interesting insights. These could include, inter alia, industry sector, union size, the degree of sophistication of workplace union organisation and the personal values of union officials. Finally, further research might examine the degree to which the work patterns of full-time officials are a symptom or cause of union membership loss in New Zealand. This could directly test the validity and nature of the relationship between structural deterministic arguments and theories which suggest unions and their officials are capable of adapting to their environments in a more strategic fashion.

\section{References}

Adams, R. (1977), The Work of the Trade Union Field Officer, Relations Industrielles, 32(4): $514-528$.

Brown, W. and Lawson, M. (1973), The Training of Trade Union Officers, British Journal of Industrial Relations, 11: 431-448.

Callus, R. (1986), Employment Characteristics of Full-Time Trade Union Officials in New South Wales, Journal of Industrial Relations, 28(3): 410-427.

Clegg, H.A., Killick, A.J., \& Adams, R. (1961), Trade Union Officers: A Study of FullTime Officers, Branch Secretaries and Shop Stewards, Oxford, Basil Blackwell. 
Cupper, L. (1983), A Profile of White-Collar Union Officials, In Ford, B. \& Plowman, D.H. (eds.), Australian Unions: An Industrial Relations Perspective, Melbourne, Macmillan.

Harbridge, R. (1993), Bargaining and the Employment Contracts Act: an overview, In Harbridge, R. (ed.), Employment Contracts: New Zealand Experiences, Wellington, Victoria University Press.

Harbridge, R. and Hince, K. (1993), Unions and Union Membership in New Zealand 19851992, New Zealand Journal of Industrial Relations, 18(3): 352-361.

Robertson, N. and Sams, K.I. (1976), The Role of the Full-Time Union Officer, Economic and Social Review, 8(1): 23-42.

Robertson, N. and Sams, K.I. (1978), Research note: on the work-pattern of union officers, Industrial Relations Journal, 9(1): 61-64. 